A. Aryamov ${ }^{1}$

Russian Academy of Justice, Moscow, Russia

V. Grachova

I. Chuchaev

V. Malikov

Moscow State Law University, Moscow, Russia
ORIGINAL SCIENTIFIC ARTICLE doi:10.5937/ekonomika1902001A

Received: March 18, 2019

Accepted: May, 08, 2019

\title{
DIGITAL ASSET AS AN OBJECT LEGAL REGULATION²
}

\begin{abstract}
In this article, the authors based on the study of the gap in the law in terms of determining the legal nature of information resources using the method of consolidation of knowledge of Economics and law (various branches of law, such as financial, tax, civil, international public... law) developed proposals for the optimization of domestic legislation, enshrining the universal economic concept of "asset"; also gave a detailed description of this concept and revealed its content.
\end{abstract}

Key words: Property, Property, Assets, Cryptocurrency, Information resources, Blockchain, Property rights, Non-property rights, Accounting, Financial law, Civil law.

Jel Classification: 030

\section{ДИГИТАЛНА ИМОВИНА КАО ПРЕДМЕТ ПРАВНЕ РЕГУЛАЦИЈЕ}

\section{Апстракт}

У овом чланку аутори су на основу проучавања празние, у правној теорији, у смислу утврђиваға правне природе информационих ресурса, користећи методу консолидовања знања економике и јуриспрудениије (различитих гране права, као што су: финансијко, пореско, грађанско, међународно-јавно... право) развили предлоге за оптимизаџију домаћег законодавства, уградивии универзални економски термин ,имовина (рус. актив) “; а такође су дали детаљан-аналитички концепт овог појма и протумачили су његов садржај.

Кључне речи: Имовина, приватна својина, активи, криптовалута, извори информација, блокланац, имовинска права, невласничка права, рачуноводствени рачун, финансијско право, грађанско право.

\footnotetext{
${ }^{1}$ aaryamov65@yandex.ru

2 "The reported study was funded by RFBR according to the research project № 18-29-16158". „Исследование выполнено при финансовой поддержке РФФИ в рамках научного проекта № $18-29-16158$ “.

${ }^{3}$ «Истраживање је извршено уз финансијску подршку РФФИ у оквиру научног пројекта № 18-29-16158».
} 
A significant problem in ensuring digital security at present is legal uncertainty regarding the regulatory definition of the concept and disclosure of the content of such an objective phenomenon as "the digital form of existence of information, the exchange and operation of it". Both in Russia and in the rest of the world, the so-called "Information law" is in the "embryonic" state. Lawyers are still in the process of understanding such phenomena as "virtual space", "blockchain", as well as the possibilities and limits of legal regulation of operating with digital information... Undoubtedly, the coming legal reform will also affect the fundamental aspects of Civil law, Financial, Administrative and Criminal law. But all this in the future.

From the point of view of intersectoral "division of labor", Criminal law (as a protective branch of law) performs an interim role in relation to social phenomena regulated by the provisions of the so-called branches "positive" rights. The thesis that Criminal law protects against socially dangerous encroachments those relations that are regulated within the framework of other (regulatory) branches of law; and it protects in the form and to the extent in which this relation has received legal regulation - is basic. But this is the ideal design of the regulatory framework and its Public law provision. Realities are often more difficult.

The process of legal regulation of a certain complex of relations may not be completed yet. But in the criminal segments of society, vectors of socially dangerous attacks on these relations are already being formed. Public branches of law (and above all Criminal law) should design a mechanism for countering such attacks, not waiting for the moment when the process of normative regulation of social relations ends in the spheres of "positive branches of law".

It is this state of affairs that is now observed in the field of legal regulation of relations in the exchange and operation of digital information. Representatives of regulatory branches of law have not even decided on the legal nature of such phenomena as "digital information", "blockchain", etc. However, for more than two decades, the system has progressed, undoubtedly characterized by the social danger of acts in the field of computer information. Criminal law cannot ignore this problem. But designing a mechanism for protecting relations in the field of digital information presupposes the definition of the object of such protection (it is also an object of socially dangerous encroachment). The blanket correspondence tool of the provisions of protective and regulatory branches of law is useless in this case.

Criminal law must cope with this task; and do it as correctly and universally as possible. So that categories, concepts and institutions formulated by criminologists would correspond to the future provisions of the regulatory branches of law, regardless of the direction in which such legal reform will proceed. The most effective in this situation is the reception of maximum regulatory abstraction.

key problem at present is the determination of the legal nature of the volume of digital information, which is the subject of regulation of the formed "Information law"; it is also the subject (and maybe an instrument or means) of socially dangerous assaults already committed. Whether his Civil law and "Informational law" will define it from the standpoint of the real right, or as a non-property right, or otherwise we cannot foresee at the moment. By virtue of what it seems appropriate to operate on the concept actively used by Financial, Tax law, Accounting and Applied economics - assets. Whichever direction the reform of Civil law and "Information law" would acquire, the proposed concept would correspond to any of them. 
In the first approximation, the concept of "asset" is widespread and claims the status of the commonly used. However, due to the specificity and complexity of its content, it needs to be defined and the study of its characteristics. Generally recognized is a concept that does not need interpretation and is understood by all in a uniform way. But even in economic dictionaries and textbooks on economics and accounting there is no uniformity in this matter; moreover, the differences in definitions are very significant; and sometimes the definitions proposed by economists, from the point of view of lawyers, are illogical.

According to a number of didactic and doctrinal sources, the economic theory by the term "assets" means (from the Latin activus - effective) collection of assets and funds belonging to an enterprise, entity, company (buildings, structures, machinery and equipment, inventories, bank deposits, securities, patents, copyrights in which owners' funds are invested, property that has a monetary value). Assets are usually divided into tangible (tangible) and intangible (intangible), the latter include intellectual product, patents, debentures of other enterprises, special rights to use resources. ${ }^{4}$

With the concept of an asset, another concept corresponds - the asset of a balance is part of the company's balance sheet, reflecting in monetary terms the tangible and intangible values belonging to the enterprise, their composition and location; excess of income over expenditure in the balance sheet. ${ }^{5}$

The above definition of an asset creates more problems than it solves (in the opinion of the authors of this study, it is extremely unfortunate); its disadvantages are:

a) the owners of the assets are far from being an exhaustive list of legal entities (many legal entities, as well as individuals, including IPBYL, are ignored);

b) in this definition, money and property are considered as equal-order phenomena, whereas by virtue of Article 128 of the Civil Code of the Russian Federation money is one of the types of property;

c) in the main text of the first sentence, only tangible phenomena are mentioned as assets - property and cash, and frankly intangible ones - copyright and patents - are given in brackets as an example;

d) and in the second sentence of the definition it is unambiguously indicated that the assets may be intangible;

e) the concept is defined in the plural - "assets", for disclosing the content of which a list of very diverse phenomena is proposed, which is subject to broad interpretation, thus the question: What is an asset and what is not? - remained unanswered.

However, the undoubted merit of the definition under consideration is to indicate such characteristics of assets as: a) they have a monetary value; b) they can be both tangible and intangible.

In the economic doctrine, the following definition of an asset is also very popular - these are property rights, as well as economic resources owned by individuals or legal entities in the form of fixed assets, including directly in the form of money, and making a profit. $^{6}$

\footnotetext{
${ }^{4}$ Райзберг Б.А., Лозовский Л.Ш., Стародубцева Е.Б.: Современный экономический словарь. 3-е издание переработанное и дополненное. ИНФА-М, М. 2000.c.17.

${ }^{5}$ См. там же.

${ }^{6} \mathrm{http} / / /$ economic-definition.com/Accounting_and_Taxes/Aktiv_Assets_eto.html
} 
This definition is also not without flaws:

a) It speaks only of fixed assets, but does not mention negotiable assets, which are also undoubtedly assets;

b) the asset may not be profitable, moreover, it may actually bring losses, the ratio of the owner of the asset to the profit from its turnover is probabilistic;

c) property rights and economic resources are defined as independent phenomena, while property rights are a type of economic resources (as well as non-property rights, which are not mentioned at all in the definition under consideration).

Eclectic masterpiece, in our opinion, is the next definition. Assets are tangible or intangible resources, such as cash and non-cash money in various currencies, securities, buildings, objects of labor, vehicles, as well as rights to works of art and literature, inventions, business reputation, trademarks, owned by a natural or legal person in various forms of ownership and capable of generating profit and increasing income in the near future or after some time. ${ }^{7}$ The level of obvious alogisms of this definition exceeds the limit, which is why a given definition does not need a separate analysis.

In a number of textbooks, the following definition is used: Assets are monetary elements of all elements of economic wealth, acquired as a result of an accomplished fact of economic activity, owned by a subject that can be used in economic activity as a source of profit. ${ }^{8}$ An example is when one vague concept - assets - is defined through another, equally vague - wealth.

Thus, given examples, in our opinion, are quite enough to generate the following conclusion: the lack of uniformity among representatives of economic doctrine in the understanding of the term "asset", despite its wide popularity in didactic and theoretical literature, it cannot be perceived as a carrier of the commonly used meaning; and, therefore, needs to be defined, preferably in the normative.

Regulatory legal regulation of turnover (as well as accounting and control over it) of assets is also difficult to recognize as optimal. The legislator often uses the term "asset" / "assets" in the design of legal norms; at the same time, in different cases it gives it a different meaning (which is clear from the context of regulatory legal acts). The text of legal norms, which contain the term "asset", often suffers from illogicality, indicating that the legislator understands very roughly the content of the concept he uses. At the same time, even attempts to construct a definition of this concept have not been undertaken at the present time.

Thus, Article 5 of the Federal Law of the Russian Federation "On Accounting" No. 402-Ф3 dated December 6, 2011 claims that the accounting subjects of an economic entity are:
1) the facts of economic life;
2) assets;
3) liabilities;
4) sources of financing its activities;
5) income;
6) expenses;
7) other objects if this is established by federal standards.

\footnotetext{
${ }^{7} \mathrm{http} / / /$ economic-definition.com/Accounting_and_Taxes/Aktiv_Assets_eto.html\#h3-0

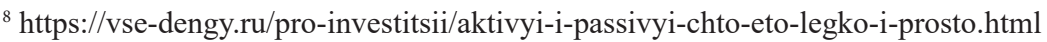


The content of this norm is very problematic. As one-order phenomena are listed: a) and the assets and facts of economic life, although the former are the result of the latter; b) both assets and revenues, while the latter are the result of the turnover of the former; c) both assets and liabilities, while the latter are a variety of the first.

The legislator used the term assets, although throughout this law does not disclose its content. Even in Article 3 of the considered regulatory legal act "Basic concepts used in this Federal Law" - the definition of this concept is absent.

The concept of "asset" is very popular in tax legislation. Art. 11 of the Tax Code of the Russian Federation "Institutions, concepts and terms used in this Code" also does not contain the definition of the term asset. Although in the text of the law the term asset is used by the legislator 77 times (Art. 25.2 - 3 times, Art. 25.13 - 6 times, Art. 25.14 ....). And nowhere is the universal definition of this term. Part 6, Article 105.5 of the Tax Code of the RF establishes the following provision: "At the same time, for the purposes of this chapter, assets are assets (property, including cash, property rights, including intellectual rights) that a person owns, uses or disposes of for income. With regard to the above definition, it seems necessary to note the following: Part 6, Article 105.5 of the Tax Code of the RF establishes the following provision: "At the same time, for the purposes of this chapter, assets are assets (property, including cash, property rights, including intellectual rights) that a person owns, uses or disposes of for income. With regard to the above definition, it seems necessary to note the following:

a) such a definition of assets for both formal and substantive grounds is relatively acceptable only for Chapter 14.2 of the RF Tax Code "General Provisions on Prices and Taxation";

b) in it they got positions that essentially contradicted the fundamentals of Civil law (which is worth attributing intellectual rights without any reservations to the number of property rights);

c) determining the purpose of using or disposing of assets (in this case, such an action as an acquisition avoided the attention of the legislator) is far from perfect - what if the entity invests in some assets not for profit, but for the purpose of saving - preservation of property status or minimizing possible losses?

d) in specific cases, Civil law operates as a tool of legal regulation with such a fiction as identification / equating property and property law (which does not comply with the basic provisions of the theory of legal relations and the mechanism of legal regulation), but in the context under consideration the use of this fiction in the construction of a legal norm seems to be unreasonable.

Part 8 Art. 142.1 of the Tax Code of the Russian Federation contains a definition of a financial asset, which in itself is nonsense - any asset is financially immanent, since its sign is monetary valuation. "Financial assets - cash, as well as securities, derivative financial instruments, equity interest in the authorized (share) capital of a legal entity or equity interest in a foreign structure without forming a legal entity, right of claim from an insurance contract, as well as any other financial instrument, associated with these types of financial assets. For the purposes of this chapter, real estate, as well as precious metals (other than impersonal metal accounts) are not recognized as financial assets." And this definition contains a number of problems, including systemic ones: 
a) from the point of view of the dialectic of the ratio of the general, special and private, this definition should at least somehow correspond with the previously considered definition of an asset, fixed in Part 6 of Article 105 of the Tax Code of the Russian Federation;

b) on the basis of this definition, real estate pledged as collateral for a bank loan even at the time of recovery is not a financial asset (although there is a transformation in "cash money";

c) the lack of exemption for movable property also looks illogical (for a sea vessel - real estate object exemption applies, and the train does not apply); d) the text of the definition contains a reservation - "for the purposes of this chapter" - that prevents the perception of this definition in the status of universal.

It should also be noted that the term "financial asset" is used by the legislator in Article 23.1 of the Budget Code of the Russian Federation without fixing its definition.

A similar state of affairs can be observed in the texts of other regulatory legal acts. Federal Law No. 140-FZ of June 8, 2015 "On the Voluntary Declaration by Individuals of Assets and Accounts (Deposits) in Banks and on Amendments to Certain Legislative Acts of the Russian Federation" and Federal Law of December 10, 2003 No. 173-FZ "On currency regulation and currency control" also contain a number of rules that enshrined the term asset, but its definition is not given anywhere.

A similar situation is observed at the level of subordinate regulatory legal acts, for example, Order of the Ministry of Finance of Russia No. 10n, FCCB of the Russian Federation No. 03-6 / pz dated January 29, 2003 “On approval of the procedure for assessing the net asset value of joint stock companies" also does not contain a definition of this concept.

May 22, 2018 The State Duma of the Russian Federation in the 1st reading adopted a draft law submitted by the Ministry of Finance of the Russian Federation, No. 4190597 "On digital financial assets", around which a broad discussion was launched. Negative conclusions were received for it:

- Committee of the State Duma of the Russian Federation on Information Policy, Information Technologies and Communications;

- Legal Department of the Staff of the State Duma of the Federal Assembly of the Russian Federation;

- Committee of the State Duma of the Russian Federation on the financial market;

- Council under the President of the Russian Federation on the codification and improvement of civil legislation;

- Committee of the State Duma of the Russian Federation on economic policy, industry, innovative development and entrepreneurship.

Many of them rightly noted that the proposed definition of a "digital financial asset" does not correspond to the notion of a "financial asset" used in Tax and Budgetary law; also that the assignment of digital assets to the category of property / real rights does not correspond to the basic concepts of Civil law.

In accordance with Article 2 of the draft Law "On digital financial assets" gives the definition of the concept of "digital financial asset" in which the following features of this economic and legal phenomenon are consolidated: 
1. property, which is accordingly subject to the right of ownership. However, in Civil law, property is an academic example of the subject of real relations as an element of the material world. In accordance with the laws of dialectics, space and time are forms of the existence of matter. It is axiomatic that the same material object at the same time cannot be in different places. The sphere of being digital financial assets - the virtual space (abstract category) - they are simultaneously located in every part of our planet and even beyond its borders. How is it possible to move such a thing in space? The question is not rhetorical. Depending on the answer to it, the problem of the jurisdiction of a state in respect of disputes and delicts arising in connection with (or in connection with) the turnover of digital financial assets is solved. The classic rule is the following: a lawsuit (application) is filed with the court (or law enforcement agency) at the location of the property (or the place of the offense - the place of damage to the property). If the subject of the dispute (tort) is a digital financial asset, then where to file a claim (application) geographically. In Article 3 (regulating the release of tokens) of the draft regulatory legal act in question contains a blanket reference to the Federal Law of April 22, 1996. №39-Ф3 “On the securities market”; the question naturally arises: should digital financial assets be considered as a type of securities? But neither in terms of emission specifics, nor in terms of subject composition, nor in accordance with the patterns of turnover, can they in principle be such.

2. The digital financial asset is in electronic form. What shape does this form have? In this case, opponents traditionally give non-cash money as an objection. But such an example is incorrect. Non-cash funds are a certain legal fiction, when the classical right of claim is conditionally perceived as an independent subject of property right; it is recognized as admissible due to the fact that non-cash money may well become cash (material and tangible) without changing its essence. A similar situation is observed with reference to non-documentary securities. A digital financial asset in its cash (material) form cannot be converted. Consequently, from the point of view of the legislator, he is in an amorphous "formless" form.

3. Digital financial assets are created using encryption (cryptographic) means. It should be noted that encryption (cryptography) is rather a method, not a means. In addition, a large number of digital resources in the virtual world participating in the information and economic circulation are created in addition to using the encryption method (for example, various open databases); moreover, at one moment they may be open, and at the next encrypted (and vice versa) - what is the chance of classifying them as digital financial assets?

4. Ownership (about the problematic perception of digital financial assets as a property subject of ownership, we spoke earlier) arises from the moment a corresponding entry is made in the register of digital transactions. A fair question arises: in the case of cryptocurrency mining, who should keep a register of digital financial asset transactions (who is the registrar, its location, what is its status, responsibility ...)?

5. Digital financial assets can have only two types: a) cryptocurrency, b) token. 
Moreover, in the same article, the definition of a token is a type of digital financial assets that is issued by a legal entity or an individual entrepreneur (and if an individual issued it, then it ceased to be a token, and what then is it?) In order to raise financing others, or there is no cash flow at all?) and is taken into account in the registry of digital records (and if its issue or movement somehow was not reflected in the registry, for example, in the case of computer fraud, then it ceased to be a token?). There is a vicious circle in defining the concept: a digital financial asset is defined as something that has the form of a token, and a token is defined as a type of digital financial asset. It seems necessary to note that in the considered definition of a token, there are no signs that would allow to distinguish it from another type of digital financial assets - cryptocurrency, which is a defect of definition. Article 3 "Features of the release of tokens" contains the provision that the emission of tokens is its alienation by the issuer to the acquirer. But the main question is: where do the tokens from the issuer come from (to what extent, when, under what security, on what basis ... are they issued)? - remains unanswered. The regulatory consolidation of an exhaustive list consisting of two types of digital financial assets generates the phenomenon of legal uncertainty regarding the definition of the legal nature of many types of information resources that are neither cryptocurrency nor token: digital customer databases, various digital information resources, online magazines with subscription fee, YouTube channels with a large number of subscribers, etc.

6. A digital financial asset cannot be a means of payment in the territory of the Russian Federation. Such a prohibition seems more than doubtful, since, for example, the essence of cryptocurrency (that is, the purpose for which it was created at all) is a means of payment. If this property is eliminated, then its every turn will be deprived of meaning. Due to the fact that the cryptocurrency exists in the "extraterritorial" virtual space, it is also meaningless to limit its turnover to the borders of the Russian Federation; even on the territory of the Russian Federation, payments by cryptocurrency are possible through the registration of a cession with residents of other states, etc. Moreover, Article 2 of the draft draft regulatory legal act contains an imperative ban on the operation of digital financial assets as a means of payment, and Article 4 states that they can be exchanged, including rubles and foreign currency. But what is such an exchange, how not to pay?

7. This is a financial asset. We have previously noted the problematic nature of the phrase "financial asset". In addition, the concept under consideration does not correspond to the above definition of a "financial asset", enshrined in Tax legislation.

The foregoing leads to the conclusion that the widely discussed draft law "On digital financial assets" is an example of a not very successful attempt to solve a very topical problem. First of all, the problem lies in the initially incorrect formulation of the problem: the pre-legislator attempted to identify digital assets solely in the light of understanding them as a financial phenomenon, which led to the emergence of systemic contradictions in the entire process of constructing legal norms. 
It seems appropriate to pay attention to international experience in optimizing and unifying the legal regulation of the turnover of various resources. In 1998 Russia joined the accounting reform program in accordance with IFRS (International Financial Reporting Standards). In 2011, in the development of this political decision, the Government of the Russian Federation adopted the "Provision on the recognition of IFRS and their explanations for use in the territory of the Russian Federation (Decree of the Government of the Russian Federation of February 25, 2011 No. 107)”. By virtue of IFRS-1. A unified definition of the general concept of assets is fixed - as resources controlled by a company as a result of past events from which the company expects economic benefits in the future'.

It is quite appropriate to take this definition as a doctrinal and applied basis for constructing a legal notion of an "asset" that corresponds to our goal. In the context of this definition (and this opinion is shared by most modern economists and accountants) assets have three main characteristics:

1. Owning an asset is aimed at obtaining probable future economic benefits on its own or in combination with other assets, which contributes, directly or indirectly, to an increase in profits or saving / preserving the economic condition of the owner (the use of the term "benefit" makes it possible to cover its content with both profit / income, no loss, saving, and even minimization of harm);

2. The asset owner can receive and control the benefits of the asset turnover (the asset turnover takes place even in the case of investing funds with the aim of saving them without the intention of alienating them);

3. A transaction or event (fact of economic activity) that served as the basis for acquiring an asset or establishing control over it or income from its turnover has already occurred (are in the past);

4. The ratio of the owner of the asset to the economic benefit from its turnover is probabilistic in nature;

5. They are subject to monetary value (this feature is absent in the definition itself, but is revealed when analyzing the context of a regulatory legal act);

6. The use of the commonly used term "resource" in the construction of a legal norm (from the French Ressource is a fundamental concept of economic theory, meaning accumulated sources and means of production) ${ }^{10}$ is optimal. A sign of a resource is its ability to quantitative changes (which, by virtue of the dialectic of the transition of quantity into quality, are capable of generating a qualitatively new economic phenomenon): concentrated / accumulation, decrease / waste, accrual / increase.

The listed signs of assets, enshrined in international legal acts of a recommendatory nature, can be taken as the basis for constructing a definition.

The asset grading, which is reflected in the national and international theory and practice of accounting and tax reporting, depending on the criterion of delineation is quite simple. Types of assets:

\footnotetext{
${ }^{9} \mathrm{https}: / /$ www.ifrs.org.

${ }^{10}$ Райсберг Б.А., Лозовский Л.Ш., Стародубцева Е.Б.: Современный экономический словарь. 3е издание, переработанное и дополненное. М. Инфа-Норм) 2000. С.341.
} 
1. According to the criterion of attitude to capital turnover: - non-current (for example, intangible assets, fixed assets, construction in progress, profitable investments in tangible assets, long-term financial investments); - current assets (for example, accounts receivable, short-term financial investments, cash, other current assets.

2. By the criterion of materiality: - material (for example, movable or immovable property); - intangible (eg, copyright, patent, business reputation).

3. According to the criterion of their reality: - Real / unimaginative - are present in the real material world and are its reflection; - Virtual / real - are present in the virtual space (for example, cryptocurrency, digital information); Fictitious - are reflected in the accounting and reporting documents, but in fact do not exist (for example, annotations as a result of fraud); - Hidden assets / real - actually exist, but are not reflected in the accounting and reporting documents (they are often used as a tool for tax evasion); - Imaginary assets / real - real assets, whose evaluation in the accounting and reporting documents is distorted (overestimated or underestimated - may also be a tool when committing economic crimes).

It is necessary to emphasize that the main characteristic of an asset is its ability to entail the extraction of any economic benefit, directly or indirectly. In this case, the economic benefit in any case should not be equated with profit or income; saving, minimizing possible harm, risk management, competitive advantage (for example, acquiring a controlling stake in a competitor to initiate a procedure for its liquidation ...). As assets in accounting, we understand any phenomenon (resource) involved in the economic turnover that can:

a) generate income;

b) accumulate financial and other benefits;

c) convert at least one of the currencies; the main property of an asset is its liquidity, i.e. the ability to turn into money (cash, non-cash, virtual), although money is also an asset. Assets can be tangible and intangible, proprietary and non-proprietary, negotiable and non-negotiable, but their integral feature is their valuation in monetary terms. The economic benefit from the turnover of assets can be both direct and indirect (for example, the cost of improving business reputation in charitable activities - business reputation is also subject to evaluation as an intangible asset in the Goodwill system).

Based on the listed properties of the asset, as well as its features, enshrined in the above-mentioned acts of international law, we believe it is possible to construct the following definition. An asset is a company involved in business turnover, having an origin from a fait accompli of business activity, having a cash value estimate of a liquid resource implying the ability of an owner to control his turnover, with the goal of direct or indirect economic benefit. This definition is advisable to fix in Article 3 of the Federal Law of the Russian Federation "On Accounting” No. 4026, 2011. "The basic concepts used in this Federal Law." All other regulatory legal acts must operate on this concept in the mode of blanket. Attempts to define this concept in tax, budgetary information and other law (examples of which have been given earlier) seem redundant. A detailed interpretation of the signs of this concept is appropriate in subordinate regulatory legal acts, for example, In the order of the Ministry of Finance of Russia No. 10n, FCCB of the Russian Federation No. 03-6 / pz dated January 29, 
2003 "On approval of the procedure for assessing the value of net assets of joint-stock companies".

In criminology, the notion of "derivative" of an asset from a crime has gained popularity: at the beginning of the causal chain of economic turnover there is a criminal asset; as a result, all the assets caused by this causal connection appear to be criminal (so, if a criminal asset is invested in a legal business, then the whole business is "infected" with criminality and criminal, the same happens when investing legal assets in the circulation of criminal funds; in this case, the fault of those who have not committed a crime is determined by the lack of due diligence and scrupulousness when choosing counterparties in business; in determining such culpability, the value of the discretion of the law enforcer is great). ${ }^{11}$

Using the concept of an asset to the prism of its definition formulated above, it is possible to give a definition of its varieties - a digital asset is an asset that exists on a digital medium (digitally processed and containing digitized information). It is advisable to fix this definition in the title and Article 2 of the draft Law "On digital financial assets" under discussion, and to make the appropriate changes in the entire text of this draft regulatory legal act. And in this form, a branch of the law of criminological orientation can take it into its scientific turn and realize the task of designing the digital security mechanism of our society. Since the subject of criminal law protection is defined - a digital asset, it seems necessary to note that it can be not only a subject of encroachment, but also an instrument or means of committing a crime).

\section{References}

Арямов А.А., Колыванцева М.А., Колыванцев А.С.:(2018). Конфискационный ресурс антикоррупционной политики. М. Юрлитинформ. С.45-56.

"The reported study was funded by RFBR according to the research project № 1829-16158”. „Исследование выполнено при финансовой поддержке РФФИ в рамках научного проекта № 18-29-16158““.

«Истраживање је извршено уз финансијску подршку РФФИ у оквиру научног пројекта № 18-29-16158».

Райзберг Б.А., Лозовский Л.Ш., Стародубцева Е.Б.: (2000). Современный экономический словарь. 3-е издание переработанное и дополненное. ИНФА-М, М.

Simonović, Z., \& Damnjanović, R. (2011). Strategijsko prilagođavanje organizacije promenama. Ekonomika, 57(1), 152-162.

http://economic-definition.com/Accounting_and_Taxes/Aktiv_Assets_eto.html

http://economic-definition.com/Accounting_and_Taxes/Aktiv_Assets_eto. html\#h3-0

https://vse-dengy.ru/pro-investitsii/aktivyi-i-passivyi-chto-eto-legko-i-prosto.html

https://www.ifrs.org.

${ }^{11}$ Арямов А. А., Колыванцева М. А., Колыванцев А. С.: Конфискационный ресурс антикоррупционной политики. М. Юрлитинформ. 2018. С.45-56. 